Proceedings of the International Scientifical Conference. Volume II: Social and Special pedagogy; Health and Sport; Overviews.

\title{
GLOBALIZATION AND ITS IMPACT ON THE EUROPEAN HIGHER EDUCATION
}

\section{Globalizācija un tās ietekme uz augstāko izglītību Eiropā}

\author{
Irina Gvelesiani \\ Ivane Javakhishvili Tbilisi State University, Georgia \\ E-mail: irinagvelesiani@yahoo.com \\ Darejan Tvaltvadze \\ Ivane Javakhishvili Tbilisi State University, Georgia \\ E-mail: darejan.tvaltvadze@tsu.ge
}

\begin{abstract}
The process of globalization acquires the greatest importance in today's world. The ongoing technological changes, the rise of the knowledge economy and the growth of skill requirements in the labor market have influenced the changes in the landscape of education throughout the world. The emergence of Bologna Process has facilitated the creation of the European Higher Education Area, which can be assumed as a sample of uniformity of the European system of higher education. The Bologna Process is focused on the following strategies: modernization of higher education; connection and creation of national, regional and global educational spaces; enhancement of the attractiveness and competitiveness of the EHEA. The implementation of these strategies implies innovative processes, which build an awareness of traditions and raise a world-wide importance and attractiveness of the Bologna process.
\end{abstract}

Keywords: Common European Framework, European Higher Educational Area, foreign language, globalization, global scale, higher education, university.

Nowadays the world is changing more and more rapidly. Social and cultural changes take place with a speed that was unimaginable even a few decades ago. The development of today's world is closely connected with the process of globalization, which builds a "global village" inhabited with the so-called "global society".

An exact date of the "emergence" of globalization is unknown. Some scholars situate its origins in the modern era, while others regard it as a phenomenon with a long history. For example: Robertson and Held acknowledge, that globalization is perhaps a pre-modern phenomenon with beginnings in the $15^{\text {th }}$ century. Thomas L. Friedman divides the history of its development into three main periods:

- period 1 (1492-1800) - the globalization of countries;

- period 2 (1800-2000) - the globalization of companies;

- period 3 (2000-present) - the globalization of individuals.

Some other theorists take more here-and-now positions, situating the beginning of the global processes at the time of the first major fuel crisis of 1973 .

However, it's worth mentioning, that since its inception, the term "globalization" has inspired a lot of competing definitions and interpretations. For example, Anthony Giddens describes it as "the intensification of worldwide social 
relations which links distant localities in such a way that local happenings are shaped by events occurring many miles away and vice versa" (Giddens A., 1990). Held, McGrew and other scholars believe, that: "globalization can be located on a continuum with the local, national and regional. At the one end of the continuum lie social and economic relations and networks; at the other end lie social and economic relations and networks which crystallize on the wider scale of regional and global interactions" (Held D., 1999). However, it's worth mentioning, that the transformation of the industrial society into the post-industrial one (during the 70s of the $20^{\text {th }}$ century) stipulated an intensive use of the word "globalization" in economic and social spheres of life. Nowadays, this term is defined as the process of integration among people, companies and governments of different nations, which is driven by international trade and investment and aided by information technology. M. Carnoy from Stanford University distinguishes two main bases of globalization - information and innovation - which are highly knowledge intensive: "Today's massive movements of capital depend on information, communication and knowledge in global markets. And because knowledge is highly portable, it lends itself easily to globalization" (Carnoy M., 2005).

All the above mentioned enables us to conclude, that globalization is the "overcoming of distance", which facilitates a free travel of people, goods and information. It makes the existed borders and boundaries irrelevant and effects the environment, culture, political systems and economic development of different countries. Moreover, we must admit, that knowledge is fundamental to globalization and vice versa - the ongoing processes increase the demand of knowledge acquisition throughout the world. The main emphasis is put on three separate levels of the educational system:

- Primary (Elementary or Fundamental) Education;

- Secondary Education;

- Higher Education (at the University level).

The given paper refers to the level of higher education and makes an attempt to discuss the development of the global European educational environment, which is created by means of ongoing changes and makes an attempt to answer the demands of the modern epoch.

The first thing we have to admit is, that globalization has changed the purpose and orientation of education in many countries. Today more and more people are investing their time and money in acquiring an appropriate knowledge than in the past. Almost all levels of education experience expansion. Hence, the rate of growth has, perhaps, been greatest at the level of higher education: „Between 1991 and 2005, the number of students enrolled in the institutions of higher education worldwide more than doubled from 68 to 137.9 million students ( UNESCO Institute of Statistics - UIS, 2007 )" (Varghese N., 2009). Such an increasing demand is stipulated by the fact, that in the context of market economy, education becomes a ,profitable venture". Studies show a close association between „investment in knowledge" and improve economic competitiveness of different countries. The higher education becomes an eligible candidate for 
Proceedings of the International Scientifical Conference. Volume II: Social and Special pedagogy; Health and Sport; Overviews. incorporation into the market framework. Therefore, the university is regarded as a provider, while the learner is a customer of its services.

The interference of globalization into the educational system of Europe stipulated the "emergence" of Bologna Process, which aims at the creation of the European Higher Education Area (EHEA). The Bologna Process is named after the Bologna Declaration, which unites 47 countries. In our opinion, its goal of sustainable innovation effects the European higher education in the following way:

\section{Bologna process modernizes higher education by focusing on the following reforms:}

- The implementation of easily readable and comparable degrees organized in a three-cycle structure (Bachelor - Master - Doctorate);

- The establishment of European Credit Transfer and Accumulation System (ECTS);

- Quality assurance;

- Fair recognition of foreign degrees and other higher education qualifications in accordance with the Council of Europe/UNESCO Recognition Convention;

- Broad access to high-quality higher education stipulated by the usage of new methodologies and facilities of teaching;

- Common basis for the elaboration of language syllabuses, curriculum guidelines, examinations, textbooks, etc. across Europe.

\section{Bologna process connects national, regional and global higher education} spaces by:

- facilitating the mobility of students, graduates and higher education staff;

- the implementation of joint study programs and research projects;

- the adoption of the Common European Framework of Reference for Languages: Learning, Teaching, Assessment (CEF).

In our opinion, the adoption of the Common European Framework is the greatest contribution, which aids European mobility by providing the objective criteria for describing language proficiency and facilitates the mutual recognition of qualifications gained in different learning contexts. The framework document has been translated into almost 40 languages (including Japanese, Chinese, Arabic and others) and since its publication in 2001it has had a wide-ranging impact on the language teaching and learning processes around the world. "The Common European Framework is intended to overcome the barriers of communication among professionals working in the field of modern languages arising from the different educational systems in Europe". It defines levels of proficiency allowing the measurement of learners' progress at each stage of learning and on a life-long basis. Common European framework has established international standards and divided "language users" into three different groups:

- Basic User,

- Independent User and

- Proficient User 
In our point of view, the importance of Common European framework increased after the global processes had reinforced the "global status" of the English language. Nowadays:

- "About 35\% of the world's mail, telexes and cables are in English.

- Approximately $40 \%$ of the world's radio programs are in English" (Globalization).

- English is the dominant language of the Internet.

- English becomes the language of science - scientific publications, international conferences, joint academic/research projects, students'/researchers' mobility or exchange programs, etc.

The given data shows the dominant role played by the "global language" in the international academia, science, media, the internet, etc. It's believed that the English language ran rampant across the globe. Persons of different nationalities learn "lingva franca" (i.e. the English language - the communicative language of the individuals of different nationalities) for functioning on the global scale. Therefore, the adoption of the Common European Framework facilitated the mutual recognition of qualifications and provided the objective criteria for describing language proficiency, that have the greatest importance in today's Europe.

\section{Bologna process creates national and regional educational spaces by:}

- reducing negative "impacts" of the English language;

- promoting linguistic diversity.

It's worth mentioning, that the spread of the English language increases the risk of uniformity and endangers the disappearance of some world languages "under the shadow" of the dominant one. The acquisition of "lingva franca" at the expanse of regional and local languages (especially in the educational system, media and public life) endangers "smaller" ones. Therefore, some European countries have to popularize national languages via teaching them as a second language (to the foreigners). We think, that even in this case, the Common European Framework becomes a useful tool for carrying out teaching, studying and assessment processes. An appropriate measurement of learners' progress via levels of proficiency simplifies learning processes and popularizes "smaller" languages. The outcomes of successful teaching process facilitate the maintenance of Europe's rich heritage of diverse languages and cultures and answer the demands of the Council of Europe (we consider the principles presented in the preamble to Recommendation R (82) 18 of the Committee of Ministers):

- $\quad$ "the rich heritage of diverse languages and cultures in Europe is a valuable common resource to be protected and developed, and that a major educational effort is needed to convert that diversity from a barrier to communication into a source of mutual enrichment and understanding;

- $\quad$ it is only through a better knowledge of European modern languages that it will be possible to facilitate communication and interaction among Europeans 
Proceedings of the International Scientifical Conference. Volume II: Social and Special pedagogy; Health and Sport; Overviews. of different mother tongues in order to promote European mobility, mutual understanding and co-operation..." (The Common...).

4. Bologna process enhances the attractiveness and competitiveness of the European Higher Education Area (EHEA) by the implementation of the main objectives of the EHEA (e.g. the new degree structure and the development of qualification frameworks, quality assurance, ECTS or the Diploma Supplement).

The strength of the Bologna Process rests on the cooperation of its member countries to create the European Educational Environment by converging important structural features of their national systems of higher education. Hence, other major strength is the enhancement of the attractiveness and competitiveness of the European Higher Education Area.

It's worth mentioning, that the relation of the European higher education with the educational systems of other parts of the world has already been defined by "The Strategy for the European Higher Education Area in a Global Setting" adopted at the Ministerial conference in May 2007. This strategy encompasses the following priorities:

- "Improving information on the European Higher Education Area,

- Promoting European Higher Education to enhance its world-wide attractiveness and competitiveness,

- Intensifying policy dialogue,

- Strengthening cooperation based on partnership and

- Furthering the recognition of qualifications" (About..., 2007).

These five core policy areas describe a common strategic framework to which all members of the Bologna process make their full contributions. Nowadays, (in the light of national priorities) each country of the European Higher Education Area endorses the policy goals and takes appropriate measures for their implementation. Moreover, all Bologna countries enhance cooperation with nonEHEA states in a spirit of partnership and solidarity aiming at mutual benefit on all levels and covering the full range of higher education programs. The relationship with different institutions of the world is reinforced by the cross-border mobility of programs, students and teachers as well as by the implementation of joint programs in the fields of research and science.

For this reason, the European model creates a considerable interest in different parts of the world. "It has a strong - and growing - appeal... In some countries, it has even been debated if "Bologna" or Bologna-like reforms should be adopted in the context of domestic higher education reform processes, and whether "Bologna" should be used to establish convergence at a regional (supranational) level" (European...).

\section{Conclusions}

Finally, all the above mentioned can be summarized in the following way: 
The process of globalization plays an important role in the formation of today's world. Its interference into the educational system of Europe has stipulated the "emergence" of Bologna Process, which rests on the cooperation of its member countries and creates the European Educational Environment by converging important structural features of the national systems of higher education. The Bologna process is focused on the development of the following strategies:

- Modernization of higher education;

- Connection of national, regional and global higher education spaces;

- Creation national and regional educational spaces;

- Enhancement of the attractiveness and competitiveness of the European Higher Education Area (EHEA).

We believe, that the implementation of these strategies implies innovative processes, which build an awareness of traditions and values. Moreover, they raise a world-wide importance of the Bologna process and enhance its attractiveness and competitiveness. We think, that in future a lot of countries will make an attempt to establish the European model of higher education in their educational systems.

\section{Summary}

Nowadays, the world is changing more and more rapidly. The development of today's world is closely connected with the process of globalization, which makes the existed borders and boundaries irrelevant and effects the environment, culture, political systems and economic development of different countries. Knowledge becomes fundamental to globalization and vice versa - the ongoing processes increase the demand of knowledge acquisition throughout the world and especially, in Europe.

The given paper discusses the Bologna Process, which includes the goal of sustainable innovation of the European higher education and encompasses different strategies, which can be presented in the following way: reforms:

1. Bologna process modernizes higher education by focusing on the following

- The implementation of easily readable and comparable degrees organized in a three-cycle structure (Bachelor - Master - Doctorate);

- The establishment of European Credit Transfer and Accumulation System (ECTS);

- Fair recognition of foreign degrees and other higher education qualifications in accordance with the Council of Europe/UNESCO Recognition Convention, etc.

2. Bologna process connects national, regional and global higher education spaces by:

- facilitating the mobility of students, graduates and higher education staff;

- the implementation of joint study programs and research projects; 
Proceedings of the International Scientifical Conference. Volume II: Social and Special pedagogy; Health and Sport; Overviews.

- the adoption of the Common European Framework of Reference for Languages: Learning, Teaching, Assessment (CEF).

3. Bologna process creates national and regional educational spaces by:

- reducing negative "impacts" of the English language;

- promoting linguistic diversity.

4. Bologna process enhances the attractiveness and competitiveness of the European Higher Education Area (EHEA) by the implementation of the main objectives of the EHEA (e.g. the new degree structure and the development of qualification frameworks, quality assurance, ECTS or the Diploma Supplement).

The implementation of these strategies acquire more and more importance in today's Europe. Innovative processes build an awareness of traditions and aim at the enhancement of the attractiveness of EHEA. Therefore, the European educational system will play a crucial role in the development of the world's educational environment.

1. About the Bologna Process (2007).

\section{Bibliography}

2. (http://www.ond.vlaanderen.be/hogeronderwijs/bologna/about/)

3. Carnoy, M. (2005). Globalization, educational trends and the open society, OSI Education Conference 2005: „Education and Open Society: A Critical Look at New Perspectives and Demands"

4. (http://www.soros.org/initiatives/esp/articles_publications/articles/globalization_20060217/ca rnoy_english.pdf)

5. European Higher Education in a Global Setting

6. http://www.ond.vlaanderen.be/hogeronderwijs/bologna/documents/WGR2007/Strategy-forEHEA-in-global-setting.pdf

7. Globalization (http://www.answer.com/topic/history-of-globalization).

8. Globalization, Economic Crisis and National Strategies for Higher Education Development

9. http://www.ond.vlaanderen.be/hogeronderwijs/bologna/documents/WGR2007/Strategy-forEHEA-in-global-setting.pdf

10. Giddens, A. (1990). The Consequences of Modernity, Polity Press, Cambridge.

11. Held, D., McGrew, A., Goldblatt, D., Perraton, J. (1999). Global Transformations: Politics,

12. Economics and Culture, Policy, Cambridge, 1999.

13. The Common European Framework in its political and educational context

14. (www.coe.int/t/dg4/linguistic/Source/Framework_en.pdf)

15. Varghese, N. V. (2009). Globalization, economic crisis and national strategies for higher

16. education development, $2009 \quad$ (http://unesdoc.unesco.org/images/0018/001864/ 186428e.pdf).

\begin{tabular}{|cl|}
\hline Irina Gvelesiani & Ivane Javakhishvili Tbilisi State University, \\
& Faculty of Humanities \\
& Chavchavadze Ave. 36, Tbilisi, Georgia \\
& E-mail: irinagvelesiani@yahoo.com \\
& Phone: +995 593 32 70 07 \\
\hline Darejan Tvaltvadze & Ivane Javakhishvili Tbilisi State University, \\
& Faculty of Humanities \\
& Chavchavadze Ave. 36, Tbilisi, Georgia \\
& E-mail: darejan.tvaltvadze@tsu.ge, Phone: +9955 57545250 \\
\hline
\end{tabular}

